\title{
Juice Quality of 'Valencia' Sweet Oranges Borne on Different Inflorescence Types
}

\author{
Graham H. Barry ${ }^{1}$ and William S. Castle \\ Citrus Research and Education Center, Institute of Food and Agricultural \\ Sciences, University of Florida, 700 Experiment Station Road, Lake Alfred, \\ FL 33850-2299
}

\section{Frederick S. Davies \\ Department of Horticultural Sciences, Institute of Food and Agricultural Sciences, University of Florida, PO Box 110690, Gainesville, FL 32611-0690}

Additional index words. Citrus sinensis, soluble solids concentration (SSC), titratable acidity (TA), within-tree variation

\begin{abstract}
The objectives of this study were to determine whether juice quality of 'Valencia' sweet orange $[C$. sinensis $(\mathrm{L}$.) Osb.] is affected by the type of inflorescence on which fruit are borne, and to determine the contribution of inflorescence type to within-tree variation in juice quality. During the 1998-99 and 1999-2000 seasons, fruit size and juice quality [soluble solids concentration (SSC) and titratable acidity (TA)] of fruit from 'Valencia' sweet orange trees on Carrizo citrange rootstock [Poncirus trifoliata $\left(\mathrm{L}_{\text {. }}\right)$ Raf. $\times C$. sinensis (L.) Osb.] planted in 1987 at Howey-in-the-Hills, Fla., were measured. A $2 \times 2$ factorial design (inflorescence type $\times$ canopy position) with leafy and leafless inflorescence types, and southwest top and northeast bottom canopy positions was used. The type of inflorescence on which fruit were borne had a minor effect on juice quality, and inflorescence type and juice quality were not directly associated. Rather, juice SSC was associated with the effect of inflorescence type on fruit size, as small fruit tended to have higher SSC than large fruit, regardless of the type of inflorescence on which fruit were borne. The relatively small difference in SSC between fruit borne on leafy and leafless inflorescences ( $\approx 3 \%$ of mean SSC) was an indirect result of fruit size. Therefore, fruit borne on leafy inflorescences, which tend to be of larger size compared with fruit borne on leafless inflorescences, tended to have marginally lower SSC. Acid content and ratio of SSC : TA were not related to inflorescence type. In addition, the type of inflorescence on which fruit were borne made only a nominal contribution to variability in juice SSC, in contrast to the major contribution of canopy position to within-tree variation in juice SSC. Factors other than inflorescence type are important components of within-tree variation in juice SSC.
\end{abstract}

Inflorescences of Citrus sp. are classified as leafy and leafless (Reece, 1945), by the number of flowers borne per floral shoot (Randhawa and Dinsa, 1947), or according to the absence or presence of leaves, the latter being sub-divided further depending on flower-to-inflorescence leaf ratio (Lenz, 1966; Sauer, 1951). Fruit set research on Citrus sp. conducted during the 1940s through the 1980 s consistently demonstrated that leafy inflorescences set a higher percentage of fruit (Jahn, 1973; Lenz, 1966; Moss et al., 1972; Reece, 1945; Sauer, 1951) and produce larger fruit (Ehara et al., 1981;

Received for publication 5 Nov. 2002. Accepted for publication 25 Apr. 2002. Florida Agricultural Experiment Station Journal Series No. R-09135. This study was made possible by partial funding from Capespan International, South Africa, and Tropicana Products Inc., Fla. The authors acknowledge the cooperation of Frank Bouis, who willingly made fruit available for this study; and Jim Baldwin, Jean Eelman, and Linda Barry for technical assistance.

${ }^{1}$ Present address: Citrus Research International, Dept. of Horticultural Science, Univ. of Stellenbosch, Private Bag X01, Matieland, 7602, South Africa; gbarry@sun.ac.za
Guardiola and Lázaro, 1987; Lenz, 1966) than leafless inflorescences. However, the two studies concerning inflorescence effects on fruit quality in Citrus are contradictory (Ehara et al., 1981; Lenz, 1966). In the earlier study (Lenz, 1966), 'Valencia' sweet orange fruit harvested from leafy inflorescences tended to have slightly higher total soluble solids (TSS) $(\approx 0.5 \%)$, titratable acidity (TA) $(<0.1 \%)$, and juice content $(<1 \%)$, despite $\approx 5 \%$ larger fruit size. There was little difference in TSS : TAratio between fruit from the two inflorescence types. In the later study with Satsuma mandarin $(C$. unshiu Marc.) (Ehara et al., 1981), fruit from leafy inflorescences were $\approx 10 \%$ larger, had less flesh relative to peel, were more advanced in rind color development, and had slightly lower juice TSS and TA than fruit from leafless inflorescences. However, these reported differences were not subjected to statistical analysis. Furthermore, the slightly lower TSS and TA reported may not have been due to inflorescence type per se, but differences in fruit size due to inflorescence type or canopy position (Harding and Lewis, 1941; Ketsa, 1988).

Besides possible inflorescence effects on juice quality, the contribution of inflorescence type to within-tree variation in juice quality is unknown. Therefore, the objectives of this study were to determine whether juice quality of 'Valencia' sweet orange was affected by the type of inflorescence on which fruit are borne, and to determine the contribution of inflorescence type to within-tree variation in juice quality.

\section{Materials and Methods}

Site and plant material. 'Valencia' sweet orange trees on Carrizo citrange rootstock planted in 1987 at 380 trees/ha in a northsouth row orientation at Howey-in-the-Hills (lat. $28^{\circ} 44^{\prime} \mathrm{N}$, long. $81^{\circ} 46^{\prime} \mathrm{W}$; elev. $23 \mathrm{~m}$ ) were used. The experimental site is located in part of the subtropical, inland area of peninsula Florida, representative of the northern Florida Ridge citrus production region. The soil type is Astatula sand (hyperthermic, uncoated Typic Quartzipsamment of the Entisol order), an excessively drained sandy soil with an organic matter content normally $<1 \%$. Trees with uniform crop load were selected from within a commercial citrus orchard, and were well cared for according to local cultural practices. The trees were irrigated with microsprinklers, and fertilized annually with $225 \mathrm{~kg} \cdot \mathrm{h}^{-1} \mathrm{~N}$. Trees were not topped, but alternate sides of trees were hedged annually to maintain a drive middle $\approx 2.4$ m-wide.

Experimental design and data collection. The experiment was conducted during the 1998-99 and 1999-2000 seasons. A $2 \times 2$ factorial design (inflorescence type $\times$ canopy position) was used to estimate inflorescence type effects on variation in juice quality where both factors were fixed. Leafy (LF) and leafless (LS) inflorescence types, equivalent to Lenz's (1966) inflorescence types C and D, were selected for the study. Four bearing shoots per treatment combination per replication (singletree replications) were tagged in late June after physiological fruit drop when inflorescence types could be easily distinguished. Leafy inflorescences had three to seven leaves, whereas LS inflorescences had no inflorescence leaves. Each inflorescence selected bore a single fruit that did not necessarily originate from a singleflowered inflorescence. To provide different conditions under which to test inflorescence effects on juice quality, two contrasting canopy microclimates were used, viz. southwest top (SWT: upper, exposed) and northeast bottom (NEB: lower, partially shaded) canopy positions (Reitz and Sites, 1948). At maturity (5 Mar. 1999 and 6 Mar. 2000), remaining tagged fruit were harvested and samples of three or four fruit per treatment combination from five (1999) or six (2000) trees were used for juice quality analysis $(\mathrm{N}=20$ in 1999 and $\mathrm{N}=24$ in 2000).

Fruit equatorial diameter and weight were measured. Juice was extracted from individual fruit using a citrus reamer (Sunkist Inc., Sherman Oaks, Calif.), and juice weight was measured to determine juice content (w/w). Brix of juice samples was measured using a hand-held temperature-compensated Brix refractometer (Atago Co., Tokyo), and TA was 
Table 1. Effect of inflorescence type (IT) on fruit size and juice quality of 'Valencia' sweet orange fruit harvested in Mar. 1999 and Mar. 2000 from southwest top (SWT) and northeast bottom (NEB) canopy positions (CP).

\begin{tabular}{|c|c|c|c|c|c|c|c|c|c|c|c|c|c|c|c|c|c|c|}
\hline \multirow{3}{*}{$\begin{array}{l}\text { Inflorescence } \\
\text { type }\end{array}$} & \multicolumn{6}{|c|}{ Fruit $\operatorname{diam}^{2}(\mathrm{~mm})$} & \multicolumn{6}{|c|}{$\operatorname{SSC}^{\mathrm{z}}(\%)$} & \multicolumn{6}{|c|}{$\mathrm{TA}^{\mathrm{z}}(\%)$} \\
\hline & \multicolumn{3}{|c|}{1999} & \multicolumn{3}{|c|}{2000} & \multicolumn{3}{|c|}{1999} & \multicolumn{3}{|c|}{2000} & \multicolumn{3}{|c|}{1999} & \multicolumn{3}{|c|}{2000} \\
\hline & $\overline{\text { SWT }}$ & NEB & $\overline{\text { Mean }}$ & SWT & NEB & $\overline{\text { Mean }}$ & SWT & NEB & Mean & $\begin{array}{l}\text { SWT } \\
\end{array}$ & NEB & $\overline{\text { Mean }}$ & $\overline{\text { SWT }}$ & NEB & $\overline{\text { Mean }}$ & $\overline{\text { SWT }}$ & NEB & Mean \\
\hline Leafy & 68.9 & 74.0 & 71.4 & 76.1 & 74.9 & 75.5 & 12.8 & 11.5 & 12.2 & 13.5 & 12.4 & 13.0 & 0.95 & 1.00 & 0.98 & 0.98 & 0.93 & 0.95 \\
\hline Leafless & 65.9 & 72.9 & 69.4 & 78.9 & 75.0 & 76.9 & 13.3 & 11.8 & 12.6 & 13.1 & 12.2 & 12.6 & 1.00 & 1.08 & 1.04 & 1.00 & 0.97 & 0.98 \\
\hline Mean & 67.4 & 73.5 & 70.4 & 77.5 & 74.9 & 76.2 & 13.1 & 11.7 & 12.4 & 13.3 & 12.3 & 12.8 & 0.98 & 1.04 & 1.01 & 0.99 & 0.95 & 0.97 \\
\hline IT & & & 0.0022 & & & 0.1684 & & & 0.0173 & & & 0.0484 & & & 0.1228 & & & 0.3575 \\
\hline $\mathrm{CP}$ & & & 0.0316 & & & 0.0461 & & & 0.0048 & & & 0.0084 & & & 0.2523 & & & 0.3908 \\
\hline $\mathrm{IT} \times \mathrm{CP}$ & & & 0.0726 & & & 0.2020 & & & 0.4239 & & & 0.3379 & & & 0.7239 & & & 0.6704 \\
\hline
\end{tabular}

${ }^{2}$ Fruit equatorial diameter, soluble solids concentration, and titratable acidity.

$\mathrm{y} 1999, \mathrm{n}=5$ trees; $2000, \mathrm{n}=6$ trees.

Table 2. Effect of inflorescence type on mean soluble solids concentration (SSC) and titratable acidity (TA) adjusted for fruit diameter (covariate) of 'Valencia' sweet orange harvested in Mar. 1999 and Mar. 2000 averaged across southwest top and northeast bottom canopy positions.

\begin{tabular}{lcclcc}
\hline Inflorescence & \multicolumn{2}{c}{ SSC $(\%)$} & & \multicolumn{2}{c}{ TA (\%) } \\
\cline { 2 - 3 } \cline { 5 - 6 } type & 1999 & 2000 & & 1999 & 2000 \\
\hline Leafy & 11.9 & 13.1 & & 0.88 & 0.94 \\
Leafless & 12.1 & 12.9 & & 0.88 & 0.98 \\
$P$-value & 0.6650 & 0.1539 & & 0.9600 & 0.1680 \\
\hline
\end{tabular}

determined by titration with $0.3125 \mathrm{~N} \mathrm{NaOH}$ and $0.5 \%$ phenolphthalein solution. The acid correction factor was added to Brix measurements to determine soluble solids concentration (SSC) (Fellers, 1990). Ratio of SSC : TA was determined.

Statistical analysis. Fruit size and juice quality variables were subjected to analysis of variance using PROC GLM(SAS Institute Inc., 1996), followed by mean separation using least significant difference (LSD). Additional analysis included analysis of covariance with fruit size as the covariate, and estimation and partitioning of variance into its components to determine the contribution of the sources of variation to total measured variation using PROC MIXED (Littell et al., 1996; SAS Institute Inc., 1996). Canopy position and inflorescence type were fixed factors, but were treated as random factors to estimate their variances.

\section{Results and Discussion}

Fruit size and juice quality. In Mar. 1999, mean fruit diameter was $\approx 70 \mathrm{~mm}$, and $\mathrm{LF}$ inflorescences bore significantly larger fruit than LS inflorescences (Table 1), but by only $2 \mathrm{~mm}$ ( $<3 \%$ difference). In Mar. 2000, mean fruit diameter was $\approx 76 \mathrm{~mm}$, and there was no difference in diameter of fruit borne on different inflorescence types. Fruit borne on LF inflorescences tend to be larger than fruit borne on LS inflorescences (Ehara et al., 1981; Guardiola and Lázaro, 1987; Lenz, 1966).

In Mar. 1999, fruit borne on LF inflorescences had significantly lower SSC than fruit from LS inflorescences, a difference of $0.4 \%$ SSC (Table 1). The opposite occurred in Mar. 2000 when fruit borne on LF inflorescences had significantly higher SSC than fruit from LS inflorescences (by $0.4 \%$ SSC). In Mar. 1999 and Mar. 2000, mean TA was $1.01 \%$ and $0.97 \%$, respectively (Table 1 ). There was

Table 3. Partitioning of variance into components for soluble solids concentration (SSC) and titratable acidity (TA) of 'Valencia' sweet orange fruit harvested Mar. 1999 and Mar. 2000 to estimate inflorescence type effects on juice quality.

\begin{tabular}{|c|c|c|c|c|}
\hline \multirow{3}{*}{$\begin{array}{l}\text { Source of } \\
\text { variation }\end{array}$} & \multicolumn{4}{|c|}{ Variance $(\% \text { of total variance })^{z}$} \\
\hline & \multicolumn{2}{|c|}{ SSC } & \multicolumn{2}{|c|}{ TA } \\
\hline & 1999 & 2000 & 1999 & 2000 \\
\hline Tree & $0.0000(0.0)$ & $0.3869(33.5)$ & $0.0043(29.4)$ & $0.0104(58.2)$ \\
\hline Canopy position & $0.9487(83.0)$ & $0.5345(46.2)$ & $0.0011(2.7)$ & $0.0004(2.1)$ \\
\hline Inflorescence type & $0.0617(5.4)$ & $0.0345(3.0)$ & $0.0014(9.4)$ & $0.0000(0.0)$ \\
\hline Error $^{y}$ & $0.1323(11.6)$ & $0.2004(17.3)$ & $0.0079(53.5)$ & $0.0071(39.6)$ \\
\hline Total & 1.1426 & 1.1563 & 0.0147 & 0.0179 \\
\hline
\end{tabular}

${ }^{2}$ Total variance partitioned into component sources of variation as estimated by PROC MIXED (Littell et al., 1996; SAS Institute Inc., 1996). Numbers in parentheses represent percentages of total measured variation.

${ }^{y}$ Error or residual variation represents sample-to-sample variation.

no significant difference in TA of fruit borne on different inflorescence types. In Mar. 1999 and Mar. 2000, The SSC : TA ratio of the juice was 12.4 and 13.4 , respectively, and in both seasons, ratio was unaffected by inflorescence type (data not shown). When the apparent relationship between SSC and fruit size was subjected to analysis of covariance, the adjusted means of SSC and TA were not significantly different between inflorescence types (Table 2).

Lenz (1966) and Ehara et al. (1981) also reported relatively small differences in juice quality associated with inflorescence type. Fruit borne on leafy inflorescences tended to produce larger fruit (Ehara et al., 1981; Guardiola and Lázaro, 1987; Lenz, 1966) with concomitant lower SSC (Ehara et al., 1981) than fruit borne on leafless inflorescences. However, any effect of inflorescence type on juice quality was apparently related to the effects of inflorescence type on fruit size, which in turn affected juice SSC (Harding and Lewis, 1940), probably by dilution of soluble solids through greater juice volume of large fruit (Sites and Camp, 1955). Therefore, fruit borne on leafy inflorescences, which tend to be of larger size compared with fruit borne on leafless inflorescences, will tend to have marginally lower SSC.

The possible advantage of inflorescence leaves being in close proximity to developing fruit (Koch, 1984), and a related increase in sink strength (Erner, 1989), did not result in higher SSC of those fruit. Photoassimilates derived from adjacent leaves may be partitioned to fruit (Koch, 1984), but allocated to cell wall components rather than to soluble constituents in juice cells, providing the advantage to leafy inflorescences to produce fruit of larger size (Ehara et al., 1981; Lenz, 1966). Alternatively, the early advantage of the presence of inflorescence leaves on increased fruit set (Moss et al., 1972) was apparently not maintained through fruit development. Furthermore, dilution of juice soluble solids may occur in larger fruit during fruit development.

In Mar. 1999, fruit borne in the NEB canopy position were significantly larger (by $6 \mathrm{~mm}$ ) than fruit borne in the SWT canopy position (Table 1). In Mar. 2000, fruit borne in the SWT canopy position were significantly larger (by $2.6 \mathrm{~mm}$ ) than those borne in the NEB canopy position. Canopy position effect on SSC was consistent over the two seasons. Fruit borne in the SWT canopy position had significantly higher SSC than those borne in the NEB canopy position, a difference of $1.4 \%$ SSC in Mar. 1999 and 1.0\% SSC in Mar. 2000. The difference in SSC between canopy positions was three times larger than the difference in SSC between inflorescence types. There was no significant difference in TA of fruit borne in different canopy positions. These effects of canopy microclimate on juice quality of Citrus sp. are well-documented (Morales et al., 2000; Reitz and Sites, 1948; Syvertsen and Albrigo, 1980), and occur independently of fruit size.

Variability in juice quality. Only $3 \%$ to $5 \%$ of total measured variance of SSC was due to inflorescence type (Table 3). In contrast, canopy position made a large contribution to variance of SSC in the two seasons (46\% to $83 \%$ ). Tree-to-tree variation $(33 \%$ of total variance in Mar. 2000) and sample-to-sample variation, represented by "error" (12\% to $17 \%$ of total variance), made intermediate contributions to total variance. For TA, $<10 \%$ of total measured variance was due to inflorescence type, whereas variation among trees (29\% to 
$58 \%$ of total variance) and variation among samples ( $40 \%$ to $53 \%$ of total variance) contributed the most to total variance.

In conclusion, the type of inflorescence on which fruit were borne in a 'Valencia' sweet orange tree had only a minor effect on juice quality of fruit, and inflorescence type and juice quality were not directly associated. Acid content and ratio of SSC : TA were not related to inflorescence type. Rather, juice SSC was associated with the effect of inflorescence type on fruit size, as small fruit tended to have higher SSC than large fruit, regardless of the type of inflorescence on which fruit were borne. The relatively small difference in SSC between fruit borne on leafy and leafless inflorescences $(\approx 3 \%$ of mean SSC) was, therefore, an indirect result of fruit size. In addition, the type of inflorescence on which fruit were borne made only a nominal contribution to variability in juice $\mathrm{SSC}$, in contrast to the major contribution of canopy position to within-tree variation in juice SSC. These data show that inflorescence type is not an important component of within-tree variation in juice SSC.

\section{Literature Cited}

Ehara, T., T. Nogata, and T. Nakamuta. 1981. Studies on fruit-bearing branches of Satsuma mandarins.
Proc. Intl. Soc. Citricult. 1:209-214.

Erner, Y. 1989. Citrus fruit set: Carbohydrate, hormone, and leaf mineral relationships, p. 233-242. In: C.J. Wright (ed.). Manipulation of fruiting. Butterworths, London.

Fellers, P.J. 1990. Florida's citrus juice standards for grades and their differences from United States standards for grades and United States Food and Drug Administration standards of identity. Proc. Fla. State Hort. Soc. 103:260-265.

Guardiola, J.L. and E. Lázaro. 1987. The effect of synthetic auxins on fruit growth and anatomical development of 'Satsuma' mandarin. Scientia Hort. 31:119-130.

Harding, P.L. and W.E. Lewis. 1941. The relation of size of fruit to solids, acid, and volume of juice in the principal varieties of Florida oranges. Proc. Fla. State Hort Soc. 54:52-56.

Jahn, O.L. 1973. Inflorescence types and fruiting patterns in Hamlin and Valencia oranges and Marsh grapefruit. Amer. J. Bot. 60:663-670.

Ketsa, S. 1988. Effects of fruit size on juice content and chemical composition of tangerine. J. Hort. Sci. 63:171-174.

Koch K. E. 1984. Translocation of photosynthetic products from source leaves to aligned juice segments in citrus fruit. HortScience 19:260-261.

Lenz, F. 1966. Flower and fruit development in 'Valencia Late' oranges, as affected by type of inflorescence and nutritional status. Hort. Res. 6:65-78.

Littell, R.C., G.A. Milliken, W.W. Stroup, and R.D.
Wolfinger. 1996. SAS system for mixed models. SAS Inst., Cary, N.C.

Morales, P., F.S. Davies, and R.C. Littell. 2000. Pruning and skirting affect canopy microclimate, yields, and fruit quality of 'Orlando' tangelo. HortScience 35:30-35.

Moss, G.I., B.T. Steer, and P.E. Kriedemann. 1972. The regulatory role of inflorescence leaves in fruit-setting by sweet orange (Citrus sinensis). Physiol. Plant. 27:432-438.

Randhawa, G.S. and H.S. Dinsa. 1947. Relation of growth to fruiting in citrus. Proc. Amer. Soc. Hort. Sci. 50:151-160.

Reece, P.C. 1945. Fruit set in the sweet orange in relation to flowering habit. J. Amer. Soc. Hort. Sci. 46:81-86.

Reitz, H.J. and J.W. Sites. 1948. Relation between positions on the tree and analysis of citrus fruit with special reference to sampling and meeting internal grades. Proc. Fla. State Hort. Soc. 54: 80-90.

SAS Institute Inc. 1996. SAS user's guide: Statistics, Version 5 ed. SAS Inst., Cary, N.C.

Sauer, M.R. 1951. Growth of orange shoots. Austral J. Agr. Res. 2:105-117.

Sites, J.W. and A.F. Camp. 1955. Producing Florida citrus for frozen concentrate. Food Technol. 9: 361-365.

Syvertsen, J.P. and L.G. Albrigo. 1980. Some effects of grapefruit tree canopy position on microclimate, water relations, fruit yield, and juice quality. J. Amer. Soc. Hort. Sci. 105:454-459. 